\title{
The role of somatostatin in 67 consecutive pancreatectomies: a randomized clinical trial
}

This article was published in the following Dove Press journal:

Clinical and Experimental Gastroenterology

7 December 2010

Number of times this article has been viewed

\section{Anastasios Katsourakis' \\ Louiza Oikonomou ${ }^{2}$ \\ Efthimios Chatzitheoklitos' \\ George Noussios ${ }^{3}$ \\ Michael Pitiakoudis ${ }^{4}$ \\ Aleksandros Polychronidis ${ }^{4}$ \\ Konstantinos Simopoulos ${ }^{4}$ \\ Antonia Sioga ${ }^{2}$ \\ 'Surgical Department of "Agios \\ Dimitrios" General Hospital, \\ Thessaloniki, Greece; ${ }^{2}$ Department \\ of Histology and Embryology, \\ School of Medicine, "Aristotelian" \\ University of Thessaloniki, Greece; \\ ${ }^{3}$ Laboratory of Sports Medicine of \\ Department of Physical Education \\ (Serres), "Aristotelian" University of \\ Thessaloniki, Greece; ${ }^{4}$ Department \\ of Surgery, School of Medicine, \\ "Democritian" University of Thrace, Greece}

Correspondence: George Noussios

Vassileos Georgiou 34

GR 54640, Thessaloniki, Greece

Tel 00302310855012

Fax 00302310 83010I

Email geornous@hotmail.com
Background: Somatostatin has been found to be effective in the prevention of postoperative complications in pancreatic surgery. It can inhibit the pancreatic secretions that, quite often, are responsible for complications during the postoperative period.

Methods: We randomized 67 patients in 2 groups. In the study group $(n=35)$, somatostatin was administered 30 minutes prior to surgery as well as intraoperatively and postoperatively. No medication was given to the control group $(n=32)$. Biopsies were taken and processed for electron microscopy and ultrastructural morphometric analysis.

Results: Administration of somatostatin reduced the exocrine granule number, and the patients suffered from fewer postoperative complications.

Conclusions: Somatostatin reduces granule number and size of pancreatic cells, which can partially explain the prophylactic effect of the drug on early complications of pancreatic surgery, and which is confirmed by the clinical findings.

Keywords: electron microscopy, pancreatic resection, somatostatin, complication, histological findings

\section{Introduction}

Release and activation of pancreatic enzymes during an operation and the postoperative period are responsible for complicating pancreatic surgery. ${ }^{1,2}$ Somatostatin can inhibit pancreatic exocrine secretion. ${ }^{3-8}$

Somatostatin involves a broad range of biological actions, which include the inhibition of pancreatic exocrine secretion. The actions of somatostatin are mediated by a family of 7 transmembrane-based G-protein-coupled receptors that comprise 5 distinct subtypes (SSTR1-5). The receptors have common signaling pathways such as inhibition of adenyl cyclase, activation of phosphotyrosine phosphatase, and modulation of mitogen-activated protein kinase. The mechanisms whereby somatostatin receptors transduce messages into intracellular responses under different conditions and in different cells are complex.

Inhibition of pancreatic exocrine secretion should improve the postoperative course and consequently reduce complications after pancreatic resection. ${ }^{9}$

The aim of this study was to assess the effect of somatostatin administration on the ultra-structure of exocrine pancreatic cells by comparing electron microscopy with clinical results.

\section{Methods}

\section{Patients}

Consecutive patients suffering mainly from pancreatic tumor $(n=60 / 67)$ and chronic pancreatitis $(n=9 / 67)$ that were suitable for pancreatic resection were enrolled in 
the study (Table 1). The patients who met the preliminary criteria were randomly assigned to receive a continuous intravenous infusion of somatostatin-14 (Somastin Sb, Faran, Athens, Greece). The dose was $3000 \mu \mathrm{g}$ within 12 hours at an infusion rate of $3.5 \mu \mathrm{g} / \mathrm{kg} / \mathrm{h}$, perioperatively (30 minutes before surgery, intraoperatively, and 7 days after surgery). The study group consisted of 35 patients and the control group 32. Patients were maintained on their usual diet and fasted for 12 hours before surgery. No patient was on total parenteral nutrition. Each patient received intravenous antibiotic prophylaxis 30 minutes preoperatively and a second dose 3 hours after the start of the operation. All patients were treated in the intensive care unit for the first 24 hours. Intravenous crystalloid solutions were administrated $(2.5-3.0 \mathrm{~L} / \mathrm{d})$ according to clinical requirements and these were supplemented by plasma or blood components in order to maintain a positive central venous pressure and a blood hemoglobin $\geq 8-9 \mathrm{~g} / \mathrm{dL}$. The patients were given nothing orally during the first 3 postoperative days. Each patient was traced up to the 90th postoperative day. The patients were treated according to the ethical guidelines of the World Medical Association Declaration of Helsinki Ethical Principles for Medical Research Involving Human Subjects adopted by the 18th WMA General Assembly, Helsinki, Finland, June 1964, as revised in Tokyo 2004. All participants gave informed consent to participation before enrolment.

\section{Study design}

The study was an open-label, parallel-group, simple randomized clinical trial and the patients were selected according to the CONSORT (Consolidated Standards of Reporting Trials) criteria.

The operations were performed and all data were collected at the hospital-based surgical department at the General Hospital “Agios Dimitrios", Thessaloniki, Greece.

The statistical analysis was performed using SPSS software (v. 15.0.1.1; SPSS Inc., Chicago, IL, USA).

The histopathological assessment and the morphometric analysis were performed at the department of Histology and Embryology, School of Medicine, Aristotelian University of

Table I Demographic findings

\begin{tabular}{llll}
\hline & $\begin{array}{l}\text { Total } \\
\mathbf{n}=\mathbf{6 7}\end{array}$ & $\begin{array}{l}\text { With } \\
\text { treatment } \\
\mathbf{n}=\mathbf{3 5}\end{array}$ & $\begin{array}{l}\text { Without } \\
\text { treatment } \\
\mathbf{n}=\mathbf{3 2}\end{array}$ \\
\hline Age & $6 I .1(37-84)$ & $62.7(37-84)$ & $61.3(41-83)$ \\
Sex (M/F) & $39 / 28$ & $22 / 13$ & $17 / 15$ \\
\hline
\end{tabular}

Thessaloniki. The review was standardized. It was performed by the same pathologist, who was blinded to the study group of the patients.

\section{Operative procedures}

After induction of general anesthesia, 13 patients underwent Kausch-Whipple operation, 46 Traverso-Longmire, 5 patients distal pancreatectomy and spleenectomy, and 1 distal pancreatectomy with preservation of the spleen (Table 2). All patients were operated on by the same surgical team using the same technique and type of materials. A 2-layer technique of end-to-side pancreatojejunal anastomosis was performed with 5/0 Monosyn ${ }^{\circledR}$ (B. Brawn Aesculap Melsungen AG) and 4/0 PDSII ${ }^{\circledR}$ (Ethicon), an end-to-side 1-layer choledochojejunal anastomosis was performed with 4/0 PDSII, and a 1-layer gastrojejunal anastomosis was performed with 4/0 Monosyn. The total operative time was an average of 6 hours for the Kausch-Whipple or Traverso-Longmire operation and 4 hours for the distal pancreatectomy. All patients, with the exception of those who underwent distal pancreatectomy, were transferred to the intensive care unit.

\section{Histopathology}

After the division of the pancreas, a small piece from the healthy tissue (pancreatic remnant) was taken for electron microscope histopathological assessment. The mean time between injection of somatostatin, tissue resection, and fixation was 3 hours. The samples were cut into smaller pieces $\left(1 \mathrm{~mm}^{3}\right)$ and fixed in $3 \%$ glutaraldehyde in phosphate buffer $\mathrm{pH} 7.4$ for 2 hours and postfixed in $2 \%$ osmium tetroxide for 1 hour. After staining with $1 \%$ aqueous solution of uranyl acetate for 14 hours, the tissue pieces were dehydrated in an increasing series of alcohol solutions and then embedded in EPON 812. After the observation of the morphology on the semi-thin sections stained with toluidine blue, thin sections were stained with lead citrate and then observed in a Jeol TEM 2000FXII at $80 \mathrm{kV}$ (Table 3 ).

Table 2 Surgical data

\begin{tabular}{lllll}
\hline & $\begin{array}{l}\text { Total } \\
\mathbf{n = 6 7}\end{array}$ & $\begin{array}{l}\text { With } \\
\text { treatment } \\
\mathbf{n = 3 5}\end{array}$ & $\begin{array}{l}\text { Without } \\
\text { treatment } \\
\mathbf{n = 3 2}\end{array}$ & P value \\
\hline Longmire-Traverso & 46 & 23 & 23 & 0.585 \\
Kausch-Whipple & I 3 & 8 & 5 & 0.45 \\
Distal pancreatectomy + & 7 & 4 & 3 & 0.783 \\
spleenectomy & & & & 0.31 \\
Distal pancreatectomy & $\mathrm{I}$ & 0 & $\mathrm{I}$ & \\
\hline
\end{tabular}


Table 3 Histopathological diagnosis

\begin{tabular}{llll}
\hline & $\begin{array}{l}\text { Total } \\
\mathbf{n}=\mathbf{6 7}\end{array}$ & $\begin{array}{l}\text { With } \\
\text { treatment } \\
\mathbf{n = 3 5}\end{array}$ & $\begin{array}{l}\text { Without } \\
\text { treatment } \\
\mathbf{n}=\mathbf{3 2}\end{array}$ \\
\hline $\begin{array}{l}\text { Pancreatic } \\
\text { adenocarcinoma }\end{array}$ & 53 & 29 & 24 \\
$\begin{array}{l}\text { Pancreatitis } \\
\text { Neuroendocrine }\end{array}$ & $\mathrm{I}$ & 5 & 4 \\
$\begin{array}{l}\text { tumor } \\
\begin{array}{l}\text { Metastatic } \\
\text { adenocarcinoma }\end{array}\end{array}$ & $\mathrm{I}$ & 0 & $\mathrm{I}$ \\
$\begin{array}{l}\text { Lymphoma } \\
\text { Acinar cell }\end{array}$ & $\mathrm{I}$ & 0 & $\mathrm{I}$ \\
Cystadenoma & $\mathrm{I}$ & 0 & $\mathrm{I}$ \\
\hline
\end{tabular}

\section{Results}

\section{Clinical findings}

Within 90 days of surgery, surgical mortality was $4.4 \%$ and morbidity was $35.8 \%$ (24/67 patients, 6 of whom were from the somatostatin group and 18 from the control group). The most frequent complication (Table 4) was fistula (25\%) followed by abscess (20.8\%), delayed gastric emptying, upper respiratory infection, urinary tract infection, fever, and multi-organ failure. The frequency of postoperative complications was lower in the somatostatin group than in the control group (Table 5). The levels of bilirubin and amylase were calculated both in serum and surgical drainage during the first, third, and fifth postoperative day in order to establish the presence of fistula or anastomosis leakage. Initially, hypoglycemia followed by hyperglycemia due to inhibition of insulin secretion, nausea, vomiting, and a burning sensation were the most common side effects of somatostatin. Mild side effects that did not rule out the interruption of the drug were observed in 3 patients who received somatostatin. Skin rash developed in 2 patients, and nausea with vomiting in one of these.

Table 4 Definition of complications

\begin{tabular}{ll}
\hline Pancreatic fistula & $\begin{array}{l}\text { Peritoneal amylase levels (drain) }>3 \times \text { plasma } \\
\text { amylase from day } 3 \text { onwards (International Study } \\
\text { Group on Pancreatic Fistula Definition) }\end{array}$ \\
Intra-abdominal & $\begin{array}{l}\text { Sterile liquid collection of at least } 5 \times 5 \mathrm{~cm} \\
\text { diagnosed on abdominal CT or ultrasonography }\end{array}$ \\
collection & Infected liquid collection confirmed by positive culture \\
Intra-abdominal & and diagnosed on abdominal CT or ultrasonography \\
abscess & 4 of the 5 following criteria: i. positive hemoculture; \\
Sepsis & ii. fever $>38^{\circ} \mathrm{C}$; iii. WBC $>12,000 / \mathrm{mm}^{3}$ \\
& or $<3000 \mathrm{~mm}^{3}$; iv. thrombocytopenia; \\
& v. metabolic acidosis \\
& Systolic pressure $<90 \mathrm{mmHg}$ or a $30 \mathrm{mmHg}$ drop in \\
Shock & systolic pressure, altered organ perfusion \\
\hline
\end{tabular}

Abbreviation: CT, computed tomography; WBC, white blood cell count.
Table 5 Postoperative complications

\begin{tabular}{lll}
\hline Total & $\begin{array}{l}\text { With } \\
\text { somatostatin }\end{array}$ & $\begin{array}{l}\text { Without } \\
\text { somatostatin }\end{array}$ \\
\hline General & $\mathrm{I}(\mathrm{I} .5 \%)$ & 0 \\
Pulmonary & $\mathrm{I}(\mathrm{I} .5 \%)$ & 0 \\
Urinary tract infection & 0 & $3(4.5 \%)$ \\
Sepsis & $\mathrm{I}(\mathrm{I} .5 \%)$ & 0 \\
Shock & $\mathrm{I}(\mathrm{I} .5 \%)$ & $2(3 \%)$ \\
Multi-organ failure & & \\
Local & $\mathrm{I}(\mathrm{I} .5 \%)$ & $5(7.5 \%)$ \\
Fistula & $\mathrm{I}(\mathrm{I} .5 \%)$ & $3(4.5 \%)$ \\
Intra-abdominal abscess & 0 & $\mathrm{I}(\mathrm{I} .5 \%)$ \\
Intra-abdominal fluid & $\mathrm{I}(\mathrm{I} .5 \%)$ & $2(3 \%)$ \\
Delayed gastric emptying & 0 & $2(3 \%)$ \\
Wound dehiscence & 0 & $\mathrm{I}(\mathrm{I} .5 \%)$ \\
Wound infection & & \\
\hline
\end{tabular}

\section{Histological findings}

In control patients the acini were normal with many membrane-bound granules of variable size, dilated rough endoplasmic reticulum, and many Golgi complexes (Figures 1 and 2).

Also, we observed dense connective tissue between the acini, some destroyed cells, and some cells with pycnotic nucleus.

The fine structure of the acinar cells after the administration of somatostatin was different. Many of the acinar cells had few granules or none at all. The electron density of membrane-bound granules varied. The cell organelles (rough endoplasmic reticulum, c. Golgi) were few (Figures 3 and 4). There were also acinar cells with a physiological appearance and many granules, as in the case of the control group. A reduction in size was observed in almost all acinar cells in more than $80 \%$ of cases.

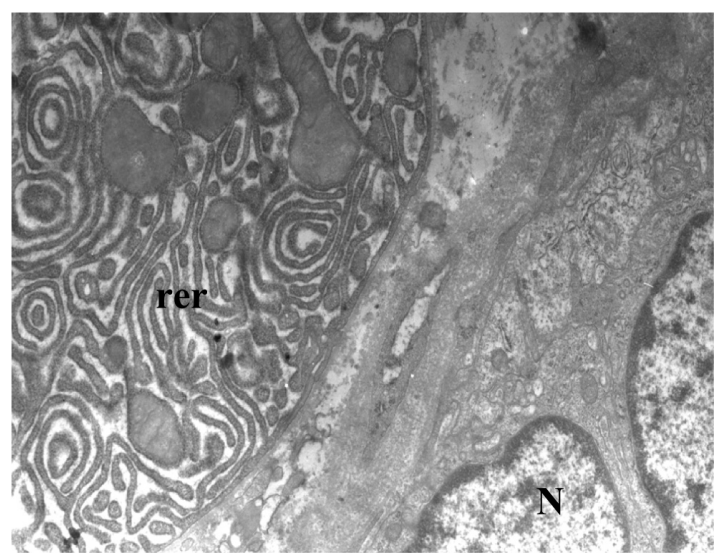

Figure I Control patient. Acinar cells with very dilated rough endoplasmic reticulum (rer).

Abbreviation: $\mathrm{N}$, nucleus $\times 8000$. 


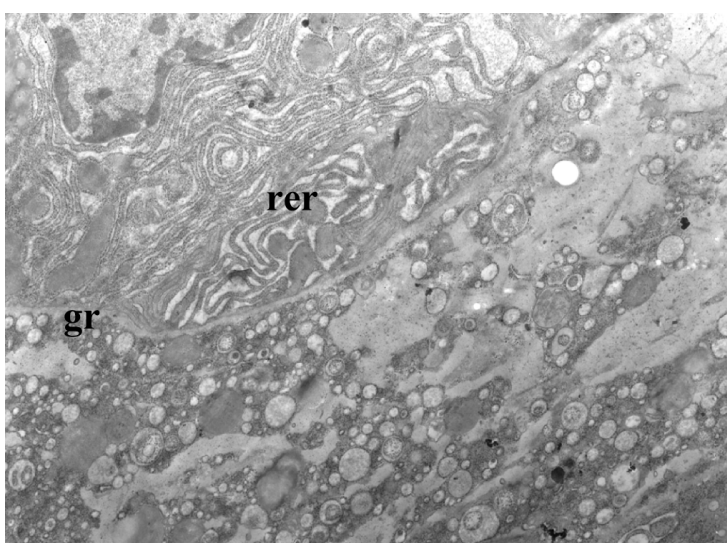

Figure 2 Control patient. Acinar cells have very dilated rough endoplasmic reticulum (rer) and granules (gr).

Selected tissue areas from the above specimens were randomized for morphometric analysis. Data were acquired by the same operator using dedicated software. In each area the number of granules and the total granular area were obtained (Table 6).

\section{Statistical analysis}

Using several statistical methods we came to the following conclusions.

Initially, 6 of $35(17 \%)$ in the treated group who received somatostatin developed complications, whereas 18 of 32 $(56 \%)$ in the control group developed complications. Then we hypothesized whether these two percentages were equal by using the simple test of equality, but this should be rejected because $\mathrm{P}=0.000$.

In order to be more accurate we used Fisher's exact test, and came to the same conclusion $(P=0.001)$, ie, the percentages of the treated group and the control group are not equal.

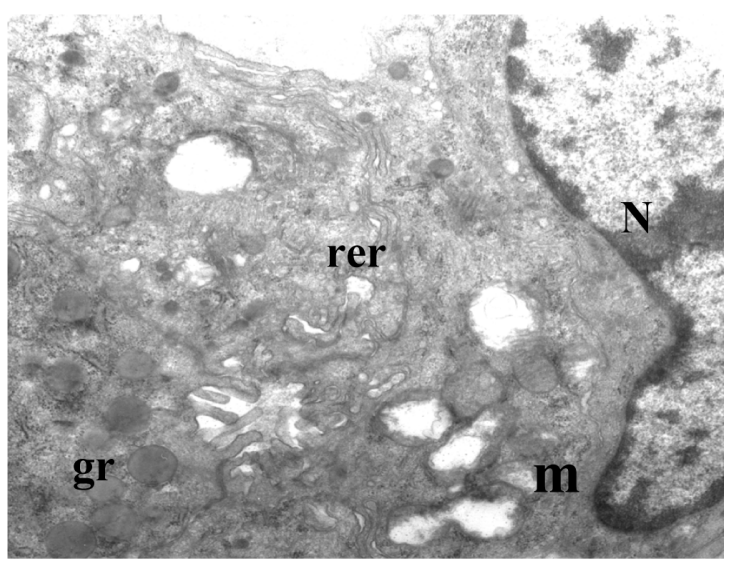

Figure 3 Exocrine acini of pancreas, with administration of somatostatin. Abbreviations: $\mathrm{N}$, nucleus; $\mathrm{m}$, mitochondria; rer, rough endoplasmic reticulum; gr, granules $\times 10,000$.

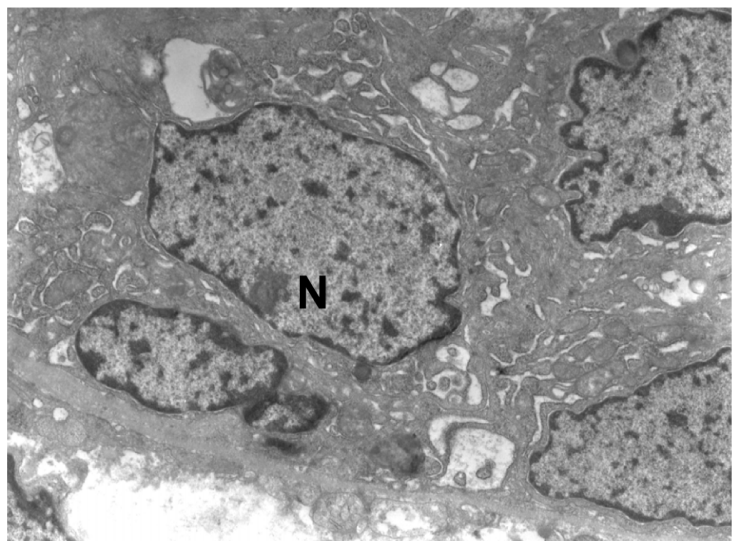

Figure 4 Exocrine acini of pancreas, with administration of somatostatin. Abbreviation: $\mathrm{N}$, nucleus $\times 5000$.

Finally, with the help of logistic regression we concluded that the patients who did not receive somatostatin (control group) had a 6.2 times higher probability of developing complications than the treatment group.

\section{Discussion}

Many clinical studies have been performed since the first observation that somatostatin, and especially its synthetic analog octreotide, can modify pancreatic exocrine secretion. Most double-blind, placebo-controlled, randomized studies have shown that administration of somatostatin in the perioperative and preoperative period reduces postoperative complications of pancreatic resection, which are currently ascribed to excess release of pancreatic enzymes. ${ }^{10}$ However, a meta-analysis of randomized controlled trials has failed to show any benefit from the administration of somatostatin, especially if the administration was done only after surgery. ${ }^{11}$ Finally, a systemic review of the Cochrane database has revealed that somatostatin can reduce the complications associated with pancreatic surgery. ${ }^{12}$

The mechanism by which somatostatin and its analog octreotide affect the exocrine secretion of the pancreas has not been adequately investigated. The administration of somatostatin reduces pancreatic enzyme secretion in response to exogenous cholecystokinin and secretin. Gullo and other researchers have shown that somatostatin can reduce amino acid uptake by the pancreas with a consequent reduction of enzymic synthesis

Table 6 Morphometric results

\begin{tabular}{lll}
\hline Group & $\begin{array}{l}\text { Mean number } \\
\text { of granules }\end{array}$ & $\begin{array}{l}\text { Total granular } \\
\text { area, } \mu \mathbf{m}^{2}\end{array}$ \\
\hline Control & $140 \pm 7.16$ & $70 \pm 6.2$ \\
Somatostatin & $101 \pm 11.3$ & $61 \pm 5.7$ \\
\hline
\end{tabular}

Note: Data expressed as mean values. 
and release, while others have demonstrated that somatostatin acts indirectly on acinar cells and inhibits secretin potentiation of secretory response by inhibiting secretin-induced c-AMP production as well as the calcium sensitivity of exocytosis. ${ }^{13-15}$ Moreover, somatostatin inhibits amylase secretion from isolated rat pancreatic acini. Other studies have suggested that somatostatin inhibits pancreatic secretion when it is injected into a central vagal site via cholecystokinin octapeptide or 2-deoxyD-glucose-stimulated pancreatic protein secretion in a dosedependent manner, and that this inhibition is via somatostatin receptor-2. ${ }^{16,17}$ Somatostatin acts on the neurons in the central vagal site, resulting in modulation of the vagal tone, thereby inhibiting pancreatic enzyme secretion. The parasympathetic innervation of the pancreas plays a major role in the control of pancreatic exocrine secretion.

In our study, the number of patients who received somatostatin (treated group) was relatively small $(n=35)$. However, ultrastructurally we observed a reduction in the synthesis of pancreatic enzymes after the administration of somatostatin. The images revealed a smaller number of granules and changes in the synthetic machinery, as confirmed by morphometric analysis as well as by statistical analysis of the clinical results.

In conclusion, the perioperative administration of somatostatin may provide some benefit in preventing pancreaticrelated complications by diminishing the synthesis of pancreatic enzymes, and is probably associated with the inhibition of exocrine secretion by the gland.

\section{Acknowledgment}

This work was supported in part by a grant from Faran laboratories s.a, Athens, Greece.

\section{Disclosure}

The authors disclose no financial or nonfinancial competing interests as well as no influence on the interpretation of data or presentation of information resulting from personal relationships with other people or organizations. AK proposed the research. All authors contributed to the study design and construction of the study protocol. AK, AS, and LO were responsible for the research. The results were discussed by all the authors.

\section{References}

1. Arvanitidis D, Anagnostopoulos GK, Giannopoulos D, et al. Can somatostatin prevent post-ERCP pancreatitis? Results of a randomized controlled trial. J Gastroenterol Hepatol. 2004;19:278-282.

2. Thomopoulos KC, Pagoni NA, Vagenas KA, et al. Twenty-four hour prophylaxis with increased dosage of ocreotide reduces the incidence of post-ERCP pancreatitis. Gastrointest Endosc. 2006;64:726-731.

3. Friess H, Bordihn K, Büchler MW, et al. Inhibition of pancreatic secretion under long-term octreotide treatment in humans. Digestion. 1994;55 Suppl 1:10-15.

4. Nakatsuka A, Yamaguchi K, Chijiiwa K, Tanaka M. Octreotide inhibits pancreatic exocrine secretion and prevents pancreatoenterostomy leakage. Int Surg. 2000;85:124-129.

5. Friess H, Büchler MW. Efficacy of somatostatin and its analogues in pancreatic surgery and pancreatic disorders. Digestion. 1996;57 Suppl 1: 97-102.

6. Uhl W, Anghelacopoulos SE, Büchler MW, et al. The role of octreotide and somatostatin in acute and chronic pancreatitis. Digestion. 1999; 60 Suppl 2:23-31. Review.

7. von der Ohe M, Layer P, Wollny C, Ensink JW, et al. Somatostatin 28 and coupling of human indigestive intestinal motility and pancreatic secretion. Gastroenterology. 1992;103:974-981.

8. Hildebrand P, Ensink JW, Gyr K, et al. Evidence for hormonal inhibition of exocrine pancreatic function by somatostatin 28 in humans. Gastroenterology. 1992;103:240-247.

9. Guan D, Maouyo D, Sarfati P, et al. Effects of SMS210-995 on basal and stimulated pancreatic secretion in rats. Endocrinology. 1990;127: 298-304.

10. Berberat PO, Friess H, Uhl W, et al. The role of octreotide in the prevention of complications following pancreatic resection. Digestion. 1999;60:15-22.

11. Zeng Q, Zhang Q, Han S, et al. Efficacy of somatostatin in prevention of postoperative complications after pancreaticoduodenectomy: a metanalysis of randomized controlled trials. Pancreas. 2008 Jan;36:18-25.

12. Gurusamy KS, Koti R, Fusai G, et al. Somatostatin analogues for pancreatic surgery. Cochrane Database Syst Rev. 2010;2:CD008370.

13. Gullo L, Pezzilli R, Barbara L. Effect of somatostatin on plasma aminoacid uptake by human pancreas. Gastroenterology. 1989;97:732-736.

14. Muller MK, Kessel B, Hutt T, et al. Effects of somatostatin-14 on gastric and pancreatic responses to hormonal and neural stimulation using an isolated perfused rat stomach and pancreas preparation. Pancreas. 1988;3:303-310.

15. Matsushita K, Okabayashi Y, Hasegawa H, et al. In vitro effect of somatostatin on secretin action in exocrine pancreas of rats. Gastroenterology. 1993:104:1146-1152.

16. Liao Z, Shen Li-Z, Lu Y, et al. Microinjection of exogenous somatostatin in the dorsal vagal complex inhibits pancreatic secretion via somatostatin receptor-2 in the rats. Am J Physiol Gastrointest Liver Physiol. 2006;292:G746-G752.

17. Li Y, Owyang C. Somatostatin inhibits pancreatic enzyme secretion at a central vagal site. Am J Physiol Gastroitest Liver Physiol. 1993;265: G251-G257.

\section{Dovepress}

\section{Publish your work in this journal}

Clinical and Experimental Gastroenterology is an international, peerreviewed, open access journal, publishing all aspects of gastroenterology in the clinic and laboratory, including: Pathology, pathophysiology of gastrointestinal disease; Investigation and treatment of gastointestinal disease; Pharmacology of drugs used in the alimentary tract;
Immunology/genetics/genomics related to gastrointestinal disease. This journal is indexed on CAS. The manuscript management system is completely online and includes a very quick and fair peer-review system. Visit http://www.dovepress.com/testimonials.php to read real quotes from published authors. 